Pamiętnik Literacki 2015, 3, s. 5-18
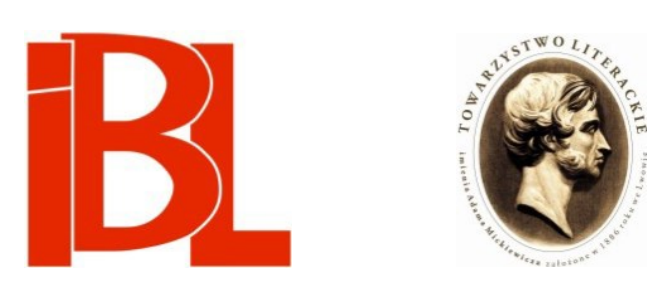

\title{
Żydzi polscy na szlaku podróży galicyjskiego globtrotera Sygurda Wiśniowskiego
}

Kazimiera Zdzisława Szymańska 


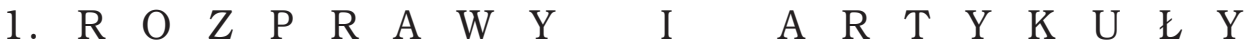

Pamiętnik Literacki CVI, 2015, z. 3, PL ISSN 0031-0514

KAZIMIERA ZDZISŁAWA SZYMAŃSKA Akademia im. Jana Długosza, Częstochowa

\section{ŻYDZI POLSCY NA SZLAKU PODRÓŻY GALICYJSKIEGO GLOBTROTERA SYGURDA WIŚNIOWSKIEGO}

Gdy w 1892 r. zakończył życie Sygurd Wiśniowski, znakomity reportażysta, powieściopisarz, nowelista i tłumacz, w prasie polskiej ukazały się artykuły poświęcone jego pamięci ${ }^{1}$. $Z$ wypowiedzi tych wynika, że krytycy i publicyści cenili dorobek śmiałego obieżyświata, zwłaszcza reportaże z 10-letniego pobytu w Australii, na wyspach Fidżi, w Nowej Zelandii i Oceanii, z wojaży po Europie (Austria, Szwajcaria, Anglia, Francja, Niemcy), z blisko 10-letniej bytności w Ameryce Północnej oraz z wyjazdów na Kubę. Podkreślali zasługi Wiśniowskiego w przybliżaniu rodakom faktów dziejowych, specyfiki poszczególnych kultur i cywilizacji. Admirowali jego człowieczeństwo, szczery patriotyzm, nagłaśnianie spraw polskich w Europie i Ameryce. Zdumiewać zatem muszą nieliczne teksty-reminiscencje przesiąknięte kąśliwością, usiłowaniem zdyskredytowania Wiśniowskiego jako patrioty i humanisty. Publikacja taka ukazała się na łamach „Biesiady Literackiej”, redagowanej przez Władysława J. Maleszewskiego (Sępa) ${ }^{2}$. Anonimowy autor pisał:

Pracował [Wiśniowski] zapobiegliwie i zdolnie, lecz aż do przesady krytykował wszystko co swojskie, wynosząc pod niebiosa pracę obcych, szczególnie Amerykanów i Żydów. Za Żydami zawsze obstawał, dał swój głos także na posła Blocha. Istniała w nim zacięta przekora, na przekór też więcej niż z przekonania był bezwyznaniowcem, a czasami zwolennikiem wiary Mojżeszowej3 ${ }^{3}$.

W przytoczonym fragmencie budzi zdziwienie próba uczynienia Wiśniowskiego przekornym krytykiem narodowych wartości, przypisanie mu przesadnej sympatii do Żydów. Oskarżenie to (nie zamierzamy dochodzić jego przyczyn) obliguje badacza twórczości galicyjskiego podróżnika do wydobycia i omówienia zobrazowanej tam kwestii żydowskiej; w dotychczasowych pracach oceniajacych dorobek Wiśniowskiego problem ten minimalizowano lub pomijano, prawdopodobnie krytycy obawiali się przyczepienia im łatki filosemitów.

1 Wspomnienia o S. Wiśniowskim zostały opublikowane w r. 1892 m.in. w „Kurierze Porannym” (nr 115), w „Tygodniku Ilustrowanym” (nr 122, s. 285), w „Gazecie Lwowskiej” (nr 93, s. 3), w „Gazecie Narodowej” (Lwów) (nr 99, s. 3).

2 W latach siedemdziesiątych i osiemdziesiątych XIX stulecia S. Wiśniowski ogłosił w „Biesiadzie Literackiej” kilka interesujących artykułów. W. J. Maleszewski (Sęp) pozytywnie zrecenzował na łamach „Biesiady” prelekcje reportera o tematyce geograficzno-przyrodniczej (1877, nr 61, s. 128130; nr 62, s. 143-146) oraz odczyt W sprawie nędzy na Ślasku (1881, nr 275, s. 211 ).

3 U. K., Śp. Sygurd Wiśniowski. „Biesiada Literacka” 1892, nr 19, s. 299. 
Prezentacja kwestii żydowskiej przez Wiśniowskiego różni się od ujęć typowych dla pozytywistów. Pisał on głównie o polskich Żydach, których spotykał na obczyźnie: w Australii, w Stanach Zjednoczonych, na Kubie. Tam poznawał ich sposób radzenia sobie $z$ trudnościami życia, rozmawiał z Izraelitami o próbach zakotwiczenia się na nowej ziemi, o emocjonalnej więzi z krajem nad Wisłą. Interesowała go sfera wyobrażeń Żydów, typ wyznawanej wiary.

Nie wgłębiając się w sprawy religijności Wiśniowskiego, chcemy wszelako zauważyć, że znał on bardzo dobrze Biblię. Często odwoływał się do jej motywów: miejsc, zdarzeń i osób. W swym życiu - co niejednokrotnie podkreślał - kierował się wskazaniami Dekalogu. W reporterskich relacjach śmiało demaskował pazerność i obłudę europejskich misjonarzy przebywających na piątym kontynencie, opisywał również szowinizm księży protestanckich osiadłych w Australii, w Stanach Zjednoczonych i w Kanadzie, ewidentnie szczepiących pogardę do wyznawców innych religii. W szkicu publicysty czytamy:

Poganinem nie jestem, [...] umiem potępić liczne bezprawia krzyczące do nieba o pomstę. Któż to nauczył jedna połowę mieszkańców wysp Polinezji bardziej nienawidzić rodaków swoich innego wyznania chrześcijańskiego niż bałwochwalców? Misjonarze Zakonu Jezusowego. [...] Kto, szczepiąc pogardę ku katolikom, zaszczepił pogardę wiary chrześcijańskiej, jeżeli nie misjonarz protestancki? Zazdrość chleba, współubieganie się zrobiło $\mathrm{z}$ najświętszego powołania arenę [... $]^{4}$.

Aby ustalić źródło zainteresowania Wiśniowskiego kwestią żydowską, warto sięgnąć do jego biografii.

Sygurd Wiśniowski pochodził ze szlachty, urodził się na galicyjskim Podolu, w regionie cechującym się różnorodnością etniczną i językową. Już w dzieciństwie miał możność obserwowania w swym środowisku spotkań kulturowych i wyznaniowych, obrazów akcentowania własnej tożsamości (konwencjonalne stroje, tańce, potrawy, manipulacja rozmaitymi przedmiotami, itp.). Tego typu doświadczenie wyposażyło przyszłego globtrotera w postawę tolerancyjną wobec „inności”, odmienności jednostek ludzkich. Przebywając na różnych kontynentach, w różnych krajach, zgromadził ogromną wiedzę socjologiczną, antropologiczną i psychologiczną. Utrzymywał bliskie kontakty z wybitnymi humanistami i przyrodnikami amerykańskimi oraz angielskimi (np. z Henrym Wadsworthem Longfellowem, Marthą Walker Cook, Thomasem Edisonem, Henrym Draperem, Thomasem Carlyle'em). Niewykluczone, że znał osobiście twórców psychologii religii: Granville’a Stanleya Halla (1844-1924), profesora uniwersytetu w Baltimore, założyciela i redaktora pierwszego czasopisma psychologicznego, „American Journal of Psychology”, oraz Edwina Dillera Starbucka (1866-1947), autora dzieła The Psychology of Religion. Mógł dyskutować z nimi na temat mechanizmów religijności, zmian zachodzących w psychice człowieka pod wpływem religii.

Jest sprawą bezsporną, że Wiśniowski należał do grupy podróżników, którzy położyli podwaliny pod nowy sposób patrzenia na cywilizację w drugiej połowie XIX

4 S. W i śn i o w s k i, Dziesięć lat w Australii. W: Koronacja króla wysp Fidżi oraz inne nowele, obrazki i szkice podróżnicze. Przedm., oprac. J. Tuwi m, B. Ols ze wi cz. Warszawa 1953, s. 70-71. Pisma wybrane. T. 1. W przedmowie (s. 42) napisano o Wiśniowskim: „Nigdzie nie atakował zasad religii chrześcijańskiej, występował jednak przeciw bigoterii katolickiej i protestanckiej oraz przeciw klerykalizmowi i nietolerancji religijnej”. 
wieku. Można powiedzieć: wyjaśniał światu świat, uznawał autonomię „innych kodów” kultury. Zgłębiał przyczyny i skutki nasilenia się procesu emigracyjnego z Europy do Australii, Ameryki Północnej i na Kubę. Jego dociekliwość poznawczą, kompetencje polityczne, antropologiczne i socjologiczne, umiejętność zachowania własnej tożsamości przy otwarciu się na „innych” docenili ludzie różnych pokoleń - np. Józef Ignacy Kraszewski, Adam Pług (Antoni Pietkiewicz), Paweł Jasienica ${ }^{5}$. Maria Konopnicka, którą interesowało zjawisko emigracji (o czym świadczy Pan Balcer $w$ Brazylii), skonstatowała:

Pan Wiśniowski jest bez wątpienia jedną z cenniejszych pereł naszego literackiego diademu, [...] jest literatem specjalistą obznajomionym $z$ tajemnicami życia i obyczajów ludności nowego świata. [...] Jest on wybornym znawcą ludów Ameryki i mistrzem w ich obiek tyw ny m a pełnym artystycznych zalet przedstawieniu.

W reportażach Wiśniowskiego kwestia żydowska wtapia się w ważne, kluczowe zagadnienia: kolonizowanie odległych kontynentów przez Europejczyków, okrucieństwo białych kolonistów wobec kolorowych tubylców, świadomość narodowa polskich wychodźców. Wielość rozpoznawanych zjawisk nie przesłoniła podróżnikowi potrzeby ujawniania twardych realiów rzeczywistości, w jakiej przyszło żyć emigrantom, przedstawiania trudności w próbach integrowania się na wychodźstwie Polaków z potomkami Abrahama.

Tematyka żydowska pojawiła się już w pierwszych reportażach Wiśniowskiego ogłoszonych na łamach „Gazety Narodowej” w 1872 roku ${ }^{7}$ W reportażu Dlaczego obiłem dwa razy komisarza Hacketta pisze on o londyńskim Żydzie, którego poznał w australijskim miasteczku Ravenswood. Na wieść, że w Europie „Francja wypowiedziała wojnę Prusom. Prusacy odnieśli świetne zwycięstwo pod Wörth!”8, mieszkańcy osady, w większości Anglicy, Francuzi i Niemcy (ci pierwsi wspierali drugich), wszczęli kłótnie, uliczne burdy, ustała nawet praca w miejscowej kopalni. Aby wyciszyć negatywne emocje, wspomniany Izraelita udał się do odległego portu i pozyskał tam od marynarzy pisemny komunikat. W drukarni dziennika „The Ravenswood Miner”, z którym współpracował Wiśniowski, „kazał natychmiast odbić kilkadziesiąt przywiezionych słów” i „na spółkę z redakcją sprzedawał pojedyncze telegramy po 5 złr. (10 szylingów), i sprzedał ich przeszło 200 w jednej godzinie"9. W następnych dniach kontynuował prace kuriera, łącznika Europy z Australią. Choć „zabił konia z pośpiechu”, odpowiadał na trudne pytania „rozciekawionej zgrai" miasteczka.

$5 \quad$ Zob. m.in. Listy Sygurda Wiśniowskiego do Józefa Ignacego Kraszewskiego (1877-1881). Oprac. K. Z. Szy mańska. „Pamiętnik Literacki” 2009, z. 4. - A. Płu g, Sygurd Wiśniowski. „Kłosy” 1881, nr 841, s. 87. - P. J a s i e n i c a, Pisarze, o których nikt nie wiedział. „Życie Literackie” 1953, nr 7 , s. 4,8 .

6 M. Konopnicka, Powieści Sygurda Wiśniowskiego. „Kłosy” 1881, nr 343, s. 124 (podkreśl. K. Z. Sz.). Zob. też A. Brodzka, Maria Konopnicka. Wyd. 2. Warszawa 1964, s. 234-238.

7 W roku 1872 na łamach „Gazety Narodowej” zamieszczono reportaże S. W iśn i ow s ki e g o w nrach: 277, 279, 280, 283, 287, 292-294, 297, 299, 306-308, 318, 339, 340, 343, 348-350, $356,359$.

8 S. Wiśniow s ki, W pogoni za nowa przygoda. Wybór, oprac. R. Przybyłow s ka-B ratk owska, S. Bratkowski. Warszawa 1979, s. 107.

$9 \quad$ Ibidem, s. 108. 
Pisząc o londyńskim Żydzie osiadłym w Ravenswood, Wiśniowski podkreśla jego wolę zachowania w środowisku „świętego spokoju”, charyzmę inteligenta, który nie plotkuje, lecz „dostarcza świadectwa”, chce podnieść kulturę polityczną wieloetnicznej zbiorowości. Czy myśli o możliwości zarobku? Niewątpliwie tak. Przybył przecież z Londynu, gdzie biedota, w tym biedota żydowska, była bardzo liczna, co więcej - ustawicznie narażona na śmierć głodową ${ }^{10}$.

Niewykluczone, że wspomniany emigrant dotarł do Anglii z Polski, by następnie przemieścić się do Australii. Chciał ułożyć sobie spójny obraz politycznej rzeczywistości, który będzie stanowił punkt wyjścia dla jego dalszych decyzji. Wiśniowski - odnotujmy w tym miejscu - na piątym kontynencie sukcesywnie gromadził wiedzę o zasłużonych emigrantach $z$ krainy przodków ${ }^{11}$.

Niezwykle interesująco prezentuje się fragment reportażu obrazującego konną podróż reportera $z$ Bathurst (Nowa Południowa Walia) do Mudgee, „miasta i okręgu słynnego z bogatych min złota, żyznej ziemi i najlepszych owiec w Australii [...]"12. Gdy wieczorem rozpiął on namiot przy czystym jeziorku i piekł mięso na węglach olbrzymiego ogniska, w pobliżu zatrzymał się wóz, na którym jechali 20-letni młodzieniec i ,jegomość już niemłody, ubrany porządnie”. Byli to - jak skonstatował syn i ojciec, „a rysy ich zdradzały pochodzenie hebrajskie” 13 . Znając australijski obyczaj, jako pierwszy „obozownik” zaprosił przybyłych na wieczerzę. Podczas kolacji wiekowy Żyd wyznał Wiśniowskiemu, że pochodzi z Polski. Dowiedziawszy się, iż jego interlokutor jest Polakiem, ponadto zaś mieszkał we Lwowie, wzruszony do łez ujawnił, że Lwów to jego rodzinne miasto, a „opuścił [je] w roku 1856”, by szukać chleba w Angliii ${ }^{14}$. Panowie chwilę rozmawiali po polsku; powrócili do języka angielskiego, chcac, by sens ich konwersacji rozumiał milczacy młodzieniec. Jak wynika z reportażu, hebrajscy goście Wiśniowskiego prowadzili w Australii obwoźny handel: sprzedawali zegarki, biżuterię i alkohol, choć akwizycja mocnych trunków była zabroniona. Świadomie łamali prawo, by więcej zarobić. Starzec zwierzył się Wiśniowskiemu, że „skoro zrobi majątek, powróci do kraju i złoży swe kości w ziemi przodków”. Przez „ziemię przodków” - udobitnijmy te słowa - rozumiał on Polskę. Pragnąc uczcić spotkanie ze współrodakiem, Izraelita poczęstował go najlepszym koniakiem, chciał też mu sprezentować „szpileczkę złota” (reporter kosztownego daru nie przyjął). Przed rozstaniem Żyd powiesił u siodła Wiśniowskiego butelkę cennej wódki. Serdecznie wzruszony powiedział: „Do widzenia we Lwowie!”15

Zob. S. W iśn ni ow ski, Z życia angielskiego. Londyn w zimie. „Gazeta Polska” 1879, nr 21, s. 2. W i śn i o w s ki, W pogoni za nowa przygoda, s. 35. Podróżnik pisał m.in. o Antonim Berezowskim (1847 - ok. 1916), działaczu niepodległościowym, uczestniku powstania styczniowego, który w r. 1867 dokonał w Paryżu nieudanego zamachu na cara Aleksandra II. Skazany na dożywotnie galery, został zesłany do Nowej Kaledonii. W jednym z reportaży australijskich S. W i ś n i o ws ki (Na kraj świata po złoto i przygody. Wybór, oprac. R. Przy był ow s k a - B r a t kow s ka, S. B ratk ow ski. Warszawa 1979, s. 162) stwierdził: „W ogóle Polacy zostawili miłe wspomnienia w Australii. Prawość, gotowość do dzielenia się całym mieniem z biednymi, gościnność i hulackie zwyczaje moich rodaków przypadły do smaku Australczykom [...]".

W is s n i o w s ki, Na kraj świata po złoto i przygody, s. 186.

Ibidem, s. 187.

Ibidem.

Ibidem, s. 188. 
Z epizodu tego wynika, że polski Żyd, emigrant, traktuje spotkanego na obczyźnie Polaka jak rodzonego brata: stąd jego rozrzewnienie, łzy, chęć dawania prezentów! Wiekowy Izraelita czuje się mocno związany ze Lwowem, z jego mieszkańcami. Tęskni za „ziemią ojców” i jest to znana nam „polska tęsknota”, o której pisali Adam Mickiewicz w Panu Tadeuszu i Sienkiewicz w Latarniku. Wiśniowski postrzega w Izraelicie człowieka szczerego, dobrego, bardzo wrażliwego, który przełamuje stereotyp Żyda-przechery, bezdusznego bogacza, wroga chrześcijan. Żyd wieczny tułacz jest mu szczególnie bliski, i jego bowiem, rodowitego Polaka, coś „nosi po świecie”. Choć ani on, ani Izraelita nie uczyli się psychologii emigracji ${ }^{16}$, posiedli niewątpliwie subtelną sztukę dialogu, która ułatwiała kontakt na obczyźnie.

Historia o polskim Żydzie znad australijskiego jeziorka, żywa, spontaniczna komunikacja interlokutorów przywodzi na myśl opublikowane 20 lat później opowiadanie Adama Szymańskiego Srul $z$ Lubartowa ${ }^{17}$. Szymański, zesłaniec syberyjski, na „nieludzkiej ziemi” spotkał wiekowego Żyda z podlubelskiego miasteczka, który w drodze na Sybir stracił troje dzieci i dorobek całego życia. Tęskni on za polską przyrodą i za polską mową. Przybył do mieszkania „rodaka”, by porozmawiać z nim o Polsce. Wygląd Żyda, jego melancholia, polska tęsknota wzruszyły narratora do łez. Odnalazł on w Srulu - posłużmy się słowami Bogdana Burdzieja: „,nie tyle Polaka, co nade wszystko - człowieka [...]"18. Podkreślmy: odnalazł Człowieka, który tak samo jak on, syn szlachty podlaskiej, odczuwał „lodowe piekło”, lęk przed śmiercią na „nieludzkiej ziemi”, przed utratą tożsamości.

W przywołanym reportażu Wiśniowski dotyka sprawy młodego pokolenia Żydów - emigrantów z Polski. Syn wiekowego Izraelity podczas wieczerzy milczy. Być może zachowuje milczenie przez szacunek dla rozmówców górujących nad nim wiedzą o świecie? Niewykluczone, iż zelektryzował go „kumplowski” charakter Polaka, jego szczera otwartość i szacunek dla Izraelitów. Prawdopodobnie młodzieniec nie zdążył związać się emocjonalnie ze Lwowem, wyjechał bowiem z Galicji, gdy miał kilka lat. Czy po śmierci ojca powróci do kraju nad Wisłą? Czy pomyśli, jak wyglądałoby jego życie, gdyby pozostał w Polsce? Trudno odpowiedzieć na te pytania. Bernard Bailyn, wybitny znawca procesów migracyjnych w XIX w., napisał: „Nie wiemy, jak zewnętrzne przejawy przekładać na język myśli, poglądów, wyobrażeń" ${ }^{19}$. Galicyjskiemu globtroterowi, który zadziwia nas swoją inteligencją oraz wrażliwością na istotę i różne aspekty tożsamości, nie chodzi wyłącznie o „moją Polskę” czy „naszą Polskę", o przywoływanie krajobrazu dzieciństwa, ale o tkwiącą w człowieku naturalną potrzebę zakorzenienia. Reporter akcentuje też istnienie zjawiska „pamięci

Zob. D. Mostwin, Emigrant polski w Stanach Zjednoczonych 1974-1984. W zb.: Polskie więzi kulturowe na obczyźnie. Red. M. Pa s zki ew i c z. Londyn 1986, s. 221. Terminologię dotyczącą emigracji, wielokulturowości, tożsamości, alternatywności dróg rozwoju historycznego wzbogacił znacząco J. Zu br zy c ki, autor artykułu Wielokulturowość $w$ teorii i praktyce (w zb.: jw.). Zob. też K. K w a śn i e w s ki, Zderzenie kultur. Tożsamość a aspekty konfliktów i tolerancji. Warszawa 1982. A. Szy mańs ki, Srul z Lubartowa. W: Szkice. Wstęp A. Gr zy mała-Si e d le c ki. Lwów 1921; wyd. 2: Warszawa 1927.

18 B. B u r d zi i j, Inny świat ludzkiej nadziei. „Szkice” Adama Szymańskiego na tle literatury zsytkowej. Toruń 1991, s. 108.

19 B. Baily n, Historyk o historii. Przeł. M. J a n n a s z. „Przegląd Humanistyczny” 1995, nr 4, s. 8. 
selektywnej”, która przetwarza rzeczywistość w mit, izoluje utraconą „małą ojczyznę” od realiów, w jakich ona istniała ${ }^{20}$.

Skomentowany tu fragment tekstu cechuje się plastycznością ujęcia partii opisowo-narracyjnych oraz żywością dialogów. „Pospolitość optyki” zwykłego uczestnika zdarzeń niewątpliwie zwiększała zainteresowanie czytelników takimi odmianami prozy dokumentalnej ${ }^{21}$.

Sprawę polskich Żydów uwzględnia Wiśniowski w swoich reportażach amerykańskich ${ }^{22}$. Na szczególną uwage zasługuje reportaż Jasełka z Manhattanu, ogłoszony w numerach 186-190 „Gazety Polskiej” z 1880 roku. Watek żydowski jest tu materiałowo obfity, eksplorowany na tyle intensywnie, że stawać się może „zapleczem informacyjnym" dla historyków ${ }^{23}$.

Dwa lata wcześniej niż Wiśniowski o polskich Żydach osiadłych za oceanem pisał Henryk Sienkiewicz w Listach z podróży do Ameryki. Sądy obu autorów różnią się zdecydowanie w pewnych obszarach. Sienkiewicz - zwłaszcza w swych początkowych tekstach - traktuje Żydów ze złośliwym humorem, z ewidentną wyższością. Dość przytoczyć tytułem przykładu fragment listu z 1877:

nie znajdziecie ani jednej najlichszej mieściny w całych Stanach, gdzie by nie było Żydka polskiego. Miałem $z$ nich nieraz sto pociech. Amerykanie nie cierpią ich dlatego, że Amerykanie oszukuja zwykle świeżo przybyłych cudzoziemców, a tymczasem polski Żydek przyjechawszy, dajmy na to, w niedzielę, w poniedziałek, o zakład, orżnął już dwóch Jankesów. [...]

I wszedzie tak ${ }^{24}$.

W przywołanym wyimku rażą nas słowa: „Żydek”, „orżnął”, „sto pociech”, „wszędzie tak"; manifestują one niechęć do Żydów, zdradzają chęć dominacji nad nimi. W kolejnym liście (9 IX 1877) Sienkiewicz udobitnia swą postawę ironisty piszac: „dla Żydów tutejszych nie mam nic więcej prócz drwinek [...]”25. Śmieszy go proces „robienia pieniędzy” przez dynamicznych Hebrajczyków, tzw. geszefty. Zdaniem Sienkiewicza, żaden Żyd polski po roku pobytu w Stanach nie jest już biedny, a „niektórzy podorabiali się milionów”26. Nasuwa się pytanie: czy Litwos posługuje

20 Zob. Człowiek, kultura, przemiany. Red. J. Płazowski, M. Suwa ra. Kraków 1998. Zob. też Z. Przy ch od niak, Walka o rząd dusz. Studia o literaturze i polityce Wielkiej Emigracji. Poznań 2001.

21 Zob. J. Szta ch els ka, „Reporteryje” i reportaże. Dokumentarne tradycje polskiej prozy w 2 pot. XIX i na pocz. XX wieku (Prus, Konopnicka, Dygasiński, Reymont). Białystok 1997, s. 15. Zob. też A. Rejter, Kształtowanie się gatunku reportażu podróżniczego $w$ perspektywie stylistycznej i pragmatycznej. Katowice 2000.

22 S. Wiś ni ow s ki opublikował liczne reportaże z pobytu w Stanach Zjednoczonych. Na szczególną uwagę zasługują teksty zamieszczone w r. 1877 w „Tygodniku Ilustrowanym”: Dom schronienia dla wyrobnic zbudowany $w$ Nowym Yorku przez T. A. Stewarta (nr 55); Radom i Kalisz $w$ Ameryce (nr 56); Katastrofa pod Ashtabula (nr 61); Piotr Kiolbassa, poseł z Chicago (nr 76); Kolej żelazna w obłokach (nr 96).

23 Na bogactwo merytoryczne reportaży Wiśniowskiego zwrócili uwagę m.in. A. Wilkoszewski (Kazimierz Pułaski. Zarys popularny. Warszawa 1929, s. 60) i J. R o s z k o (Ostatni rycerz Europy. Katowice 1984, s. 397).

24 H. Sienkiewi c z, Listy z podróży do Ameryki. Warszawa 1988, s. 341; zob. też s. 397 (szkic Osady polskie w Stanach Zjednoczonych Północnej Ameryki).

25 Ibidem, s. 343.

26 Ibidem. 
się żartobliwym językiem, aby uzyskać efekt artystyczny, czy też gra rolę ukrytego szydercy usytuowanego w jakimś „międzykontynentalnym przeciągu”27? Odsuwamy zbyt prostą supozycję, że był wówczas zarażony wirusem antysemityzmu.

$Z$ upływem czasu Sienkiewicz zmienia nieco swój stosunek do polskich Żydów w Ameryce. Pisze: „powiem wam poufnie, że mam dla nich wiele szacunku”. I dalej: „Tu dopiero przekonałem się, jaka to energiczna i przedsiębiorcza jest ludność"28. O tej zmianie stanowiska (dziwić może stwierdzenie: „powiem wam poufnie”) zadecydowały prawdopodobnie rozmowy z mieszkającymi wtedy w Stanach Zjednoczonych dziennikarzami: Julianem Horainem i Edmundem Z. Brodowskim, tudzież obserwacja polskich chłopów-emigrantów, zagubionych w rzeczywistości amerykańskiej. Wówczas Litwos dostrzegł potrzebę konsolidacji Polaków i polskich Żydów w Stanach Zjednoczonych. Stwierdził:

położenie rzeczy zmieniłoby się niezawodnie, gdyby w ogólny ustrój, mający wprowadzić jedność wewnętrzną między Polakami, weszli i Żydzi. [...] nic by więc nie przeszkadzało przyłączeniu się Żydów do rozlicznych towarzystw polskich, gdyby nie to, że towarzystwa te noszą charakter kościelno-religijny, uwzględniający tylko Polaków wyznania katolickiego. Samym Żydom nie brakłoby ochoty. Słyszałem to z ust wielu $z$ nich. Nie potrzebuję zaś dodawać, że przyniosłoby to nieobliczone korzyści. Wszystkie zamiary organizacyjne rozbijają się tu wiecznie o brak funduszów. Otóż Żydzi mają fundusze. [...] Polacy mogliby to mieć wszystko, gdyby byli liczniejsi i bogatsi, a byliby liczniejsi i bogatsi po połączeniu się z Żydami polskiego pochodzenia, które to połączenie nie nastapiło i nigdy nie nastąi ze względu na przeszkody, jakie stawiać mu będą duchowni ${ }^{29}$.

Dobrosława Świerczyńska w zamieszczonym w „Pamiętniku Literackim” artykule Sienkiewicz i Żydzi cytuje liczne (drukowane) wypowiedzi Sienkiewicza na tematy żydowskie. Komentuje poglądy Litwosa zawarte w tekście Osady polskie $w$ Stanach Zjednoczonych, pisanym w r. 1877, a opublikowanym rok później w „Przeglądzie Tygodniowym”:

Polakom w Ameryce grozi - według Sienkiewicza - „rozpłynięcie się” w żywiole amerykańskim lub niemieckim, wynarodowienie i jednocześnie odizolowanie się od wieloetnicznego społeczeństwa, właśnie z powodu ubóstwa organizacyjnego, wynikającego zarówno z ubóstwa materialnego, jak i ze zbyt silnego pierwiastka religijno-kościelnego; przykościelne szkółki niedzielne i wojujące ze sobą o prenumeratorów, czyli o przetrwanie, polskie gazety - nie poprawią sytuacji ${ }^{30}$.

Jak dalej pisze Świerczyńska: „Podobne poglądy (i sformułowania!) znajduja się w artykule pt. Osady polskie w Stanach Zjednoczonych Pótnocnej Ameryki",

Zob. J. Ka n d zi or a, Między wyobraźnia traumatyczną i geometryczną. Filozoficzne przestrzenie „Chirurgicznej precyzji” Stanisława Barańczaka. I. „Pamiętnik Literacki” 2003, z. 2, s. 153. Na fakt, że korespondencje Sienkiewicza z Ameryki „są pełne żartobliwego nastroju przechodzącego czasami w przesadną karykaturalność”, zwrócił uwagę P. C h mi elow s ki (Pisma krytycznoliterackie. Oprac. H. Marki ewi cz. T. 1. Warszawa 1961, s. 471). Zdaniem B. Burdzi ej a (Topika „Psalmu” 136 〈137〉 w strukturze ideowej „Niewoli tatarskiej”, „Tej trzeciej” oraz „We mgle” Sienkiewicza. W zb.: Henryk Sienkiewicz i jego twórczość. Red. Z. Przybyła. Częstochowa 1996, s. 113): „Sienkiewicz, rzadko wypowiadający się na tematy żydowskie, daleki był zarówno od filosemityzmu Orzeszkowej z lat siedemdziesiątych-osiemdziesiątych, jak i hiperkrytycznej postawy Jana Jeleńskiego".

28 Sienkiewicz, op. cit., s. 343.

29 Ibidem, s. 380.

30 D. Świer czyńs ka, Sienkiewicz i Żydzi. Rekonesans. „Pamiętnik Literacki” 2008, z. 2, s. 133. 
ogłoszonym przez Sienkiewicza w r. 1879 w dodatku „Gazety Lwowskiej”. W polskich osadach w Ameryce - naświetla badaczka informację Litwosa - jest niewielu Żydów, „bo lepiej im i swobodniej w większych jankeskich miastach, bliżej centrów handlowych oraz placówek bankowych"31.

W przywołanym przez Świerczyńską artykule z 1879 r. Sienkiewicz zarzucił polskim Żydom współpracę $\mathrm{z}$ miejscowymi przestępcami:

Grzecznością, dobrym słowem, a przede wszystkim kredytem ujmuja oni sobie zwykle najgroźniejszych awanturników lub regulatorów 〈tj. wykonawców prawa lynchu〉, a zjednawszy raz dla siebie ich rewolwery, handlują już pod ich opieką bezpiecznie. 〈...〉 Widziałem istniejące w tych warunkach sklepy naszych Żydów w Dedwood (Wyoming), w Darwin (Kalifornia), Virginia City (Nevada). Właściciele ich w ciagu kilku może lat staną się milionerami ${ }^{32}$.

W porywie reporterskiej retoryki Litwos niejednokrotnie fundował polskim czytelnikom wydumaną ciekawostkę. „Koloryzował” też rzeczywistość, korzystając m.in. $\mathrm{z}$ amerykańskiej literatury ${ }^{33}$.

Julian Krzyżanowski, oceniając amerykańskie korespondencje Sienkiewicza, postrzega w nich „niezupełnie cenzuralne koncepty humorysty” ${ }^{34}$. Wybitny znawca twórczości tego autora, Tadeusz Bujnicki, we wstępie do Wyboru nowel i opowiadań Sienkiewicza stwierdził:

sądy pisarza w nadsyłanych korespondencjach, znanych reportażach pt. Listy z podróży, a także w twórczości literackiej są nierzadko sprzeczne i zmienne ${ }^{35}$.

Bez wątpienia Wiśniowski lepiej niż Litwos orientował się w kwestii żydowskiej. Dłużej wszak przebywał za oceanem, na bieżąco obserwował procesy asymilacyjne, różne aspekty przystosowania się do nowej rzeczywistości. Z prawdziwym humanizmem odnosił się do wszystkich Izraelitów, którzy wyemigrowali za ocean. W reportażu Jasełka z Manhattanu podkreślił, że wśród wychodźstwa europejskiego w Nowym Jorku mieszka przeszło „300 000 Niemców, tyluż Irlandczyków, 100000 Anglików i Szkotów [...], 50000 Żydów"36. Według ustaleń autora Izraelici polscy - podobnie jak Polacy - najczęściej przybywają do Stanów zachęceni przez agentów, „ludzi bez sumienia”, przez „węże wkradające się pomiędzy lud naiwny pod złudnym

31 Ibidem.

32 Ibidem, cyt. na s. 133-134.

33 Zob. J. R. Kr zy ża n ow s ki, Na kalifornijskim szlaku Sienkiewicza. Jw., 2003, z. 2, s. 84-85, 90. „Koloryzowanie” pisarza J. R. Krzyża n ow s ki omawia w pracy 0 „kawaleryjskich dowcipach” Sienkiewicza („Nowy Dziennik / Polish Daily News” nr 8689 〈2003〉, dodatek: „Przegląd Polski”). J. Krzy ża n ow s ki, Henryka Sienkiewicza żywot i sprawy. Warszawa 1966, s. 69.

35 T. Bujnicki, wstęp w: H. Sienkiewi cz, Wybór nowel i opowiadań. Oprac. ... Wyd. 3, skrócone. Wrocław 1988, s. XXXVI. BN I 231. T. B u j n i cki w artykule Sienkiewicz wczoraj i dziś (w zb.: Spotkanie sienkiewiczowskie. Opole, 24-25 X 1996. W sto pięćdziesiata rocznice urodzin i osiemdziesiąta rocznicę śmierci pisarza oraz $w$ stulecie powstania „Quo vadis?” Red. Z. P i a s e cki. Opole 1997, s. 17) apeluje do badaczy: „"sprawa Sienkiewicza"-twórcy jest nadal otwarta. Zasadniczym zadaniem interpretatora staje się przełamanie stereotypu lektury i stereotypu genezy światopoglądu pisarza. Temu celowi winno służyć lepsze rozpoznanie artystycznego warsztatu i funkcji dzieł Sienkiewicza”.

36 S. Wiśniowski, Jasełka z Manhattanu. „Gazeta Polska” 1880, nr 186, s. 1. Dalej lokalizuję cytaty $\mathrm{z}$ tego reportażu podając $\mathrm{w}$ nawiasie numer pisma i stronicę. 
swojskim nazwiskiem"37. W reportażu tym znajdujemy szczegółowe opisy przestrzeni, w której funkcjonuja polscy Żydzi:

Jedna część Bovery (New York) nazywa się Chatham Street. Jest to Jerozolima amerykańskiego Izraela polskiego pochodzenia. Wzdłuż niej i wzdłuż Bovery spotkamy niemało szyldów z nazwiskami na -ski, a rodakom świeżo przybyłym z Europy zwykle się przytrafia, gdy idą ulicą Chatham i rozmawiają cokolwiek głośno po polsku, że ich przytrzyma elegancki młodzieniec i zapyta grzecznie:

- Ny, czy wielmożni panowie nie dadzą co utargować?

Sklep na Chatham Street jest ideałem przybyłego z Polski Żydka. [nr 188, s. 1]

Stosując zdrobnienie „Żydek”, Wiśniowski nie żartuje ze „starszych braci w wierze”. Jest wyraźnie wzruszony, gdy daleko od ojczyzny słyszy kaleką polszczyznę Izraelitów. Nie potwierdza też sądu Litwosa, że wszyscy polscy Żydzi w Ameryce są bogaci. Wedle ustaleń Wiśniowskiego żydowscy emigranci przybyli na Manhattan otrzymuja „kilka dolarów zapomogi od stowarzyszenia Izraelitów” (nr 188, s. 1). Dzięki wsparciu filantropów zaczynają zarabiać na życie, zajmując się obnośnym handlem (sprzedają głównie krawaty i sztuczną biżuterię). Dorobiwszy się nieco grosza, zakładają kramy w suterenach kamienic. Dotychczasowy towar zastępuja książkami, parasolami i odzieżą. Na brak klientów nie narzekają, Amerykanki bowiem lubią się stroić, przeglądają „świecidła i gałganki po sklepach całymi godzinami” (nr 186, s. 1).

Kolejna pozycją w awansie handlowym polskich Żydów są magazyny gotowej odzieży, a następna - kantory wymiany walut przy Wall Street: „ulicy giełdziarskiej, gdzie każdy kantor i każda piwnica bywa sceną olbrzymich wymian pieniężnych i szalonych spekulacji, gdzie majątki idą w miliony" (nr 186, s. 1). Choć na wszystkich stanowiskach handlowych Żydzi zachowują się skromnie i grzecznie, nie zaznają spokoju ze strony Amerykanów, Irlandczyków oraz Niemców, „zarażonych wirusem kolonializmu”. W szczególności Niemcy są niechętni wobec konkurujących z nimi Hebrajczyków. Traktują ich jak intruzów. Co więcej - oskarżają rywali handlowych o najdrapieżniejsze instynkty ludzkie, m.in. wzniecanie pożarów (zob. nr 188, s. 2). Są to oskarżenia bezpodstawne, wszelako rzucają cień na obwinionych. Amerykanie i Niemcy - stwierdza reporter - „próbują wyłączać bogaczów semickich z miejsc zabaw publicznych" (nr 188, s. 2), odmawiają im przyjmowania do hoteli, miejsc kapielowych, teatrów. Zdaniem Wiśniowskiego, agresja Niemców wobec polskich Żydów, przenoszona na Polaków, jest toksyczna:

Ich nienawiść przeciw Izraelitom daje się czuć Polakom w ogóle, albowiem nie umieją znaleźć różnicy między Lechitami i Semitami. Niejedno pogardliwe zdanie o Polakach spotykane w niemieckoi angielsko-amerykańskiej prasie było wymierzone przeciw Semitom, a trafiało w ogół. [nr 188, s. 2]

Polacy ostro reagują na rzucane obelgi, Żydzi natomiast „drwią sobie $z$ tej nienawiści, zbogacają się na przekór niej, monopolizują z swego ogniska przy Bovery wszystek handel gotowymi sukniami w Stanach Zjednoczonych" (nr 188, s. 2).

Czy problem antysemityzmu Niemców galicyjski globtroter wyolbrzymia? Sądzimy, że nie. Arogancję, snobistyczna pychę kolonizatorów niemieckich wobec innych nacji i wyznań dostrzegł już w Australii. W Stanach Zjednoczonych utwier- 
dził się tylko w swych przekonaniach. Wypada tu zaakcentować, że również Sienkiewicz, mając osobisty kontakt z Niemcami w Kalifornii, odniósł niekorzystne wrażenia $^{38}$. Znalazły one odbicie np. w noweli Sachem (1883).

W Nowym Jorku - pisze Wiśniowski - funkcjonują liczne szynki, których właściciele, otyli Niemcy, rozpijaja „najbardziej desperackie żywioły Manhattanu” (nr 188, s. 2). Krwawe burdy, powtarzające się co noc, dotykają zwłaszcza Polaków i polskich Żydów. Żydzi - jak już zaznaczyliśmy - są niezwykle odporni na upokorzenia, na trudy egzystencji. Pracują od rana do nocy. Szereg ich straganów przy ulicy (pierwszy i drugi stopień kupiectwa) przypomina reporterowi jarmark warszawski za Żelazną Bramą (jak na obrazie Aleksandra Gierymskiego Brama na Starym Mieście). Dorosłym Hebrajczykom towarzyszą przeważnie ich bystre dzieci, które uczą się „robić pieniądze”. Imponuje im szalony wir życia wielkiego miasta.

Wiśniowski podważa stwierdzenie Sienkiewicza, że wszystkim polskim Żydom osiadłym w Ameryce udaje się osiagnąc stabilizację materialną. Wielu z nich przegrywa $\mathrm{w}$ walce $\mathrm{z}$ przeciwnościami losu. Czytamy w reportażu globtrotera:

Ten pracowity pielgrzym z Nalewek krąży jednak wciąż po zaułkach zamorskiej stolicy, coraz starzej wyglądając, i nędzniej, i smutniej - istny portret Żyda wiecznego tułacza. [nr 189, s. 1]

Niektórzy z Semitów - notuje Wiśniowski - „błądzą i błądzą... na śmierć. Biedna ich dola!” Część Żydów - przybyszów z Polski - „wyciaga ręce i żebrze, u drzwi domów na rogach ulic, wszędzie, chociaż tutejsze ustawy traktują żebraków jak zbrodniarzy" (nr 189, s. 1).

Widok hebrajskich współbraci-jałmużników pogrążonych w głębokiej traumie niewątpliwie budził współczucie galicyjskiego globtrotera. Jak wnosimy z jego reportażu, zapraszał on zziębniętych, głodnych polskich Żydów do tanich garkuchni na posiłek. Wtedy rozmawiał $z$ nimi na temat „doświadczenia nowoczesności”: o szerokich planach nakreślonych w Polsce i dotkliwych porażkach w Stanach Zjednoczonych. Wnikał w ich prywatność. Miał możność zgłębienia biografii ludzi reprezentujących różne warstwy społeczne, nie wyłączając inteligencji. U wychodźców hebrajskich postrzegał cechy polskie, bliską więź z polską kulturą, w której tworzeniu - co wypada zaakcentować - ich przodkowie odegrali trudną do przecenienia rolę. Starał się stworzyć biedakom na obczyźnie klimat rodzinny. Warto też udobitnić fakt, że Wiśniowski konsekwentnie eksponował problemy polskich Żydów-emigrantów, celowo fałszowane przez propagandę antysemicką w prasie krajowej, warszawskiej i lwowskiej. Był typem buntownika.

W reportażach Wiśniowskiego pojawia się motyw aktywności politycznej polskich Żydów za oceanem. W Nowym Jorku - stwierdza podróżnik - rozpowszechniana jest plotka, że Izraelici prowadzą zakazane przez prawo działania przeciwko ustrojowi społecznemu, stanowiąc zagrożenie dla innych emigrantów. Przytacza słowa swojej gospodyni, Irlandki, wedle której każdy Żyd ,jest komunistą, wywołuje wszystkie socjalistyczne wiece i zaburzenia, a przez to zapewnia sobie, ażeby szyby się tłukły i nie brakowało mu zatrudnienia”. Kobieta czuje antypatię do Żydów. Mówi: „gdyby nie ci szklarze, gdyby nie ci pańscy rodacy, nasi poczciwi Irlandczy- 
cy nigdy by się nie zbierali z kamieniami na walne mityngi komunistyczne" (nr 189, s. 1).

W tym miejscu rodzi się pytanie: jak kształtowała się wiedza wspomnianej Irlandki o polskich Żydach? Z reportażu Wiśniowskiego wynika, że o zagrożeniach politycznych ze strony Polaków i polskich Żydów pisały miejscowe gazety. Konkluduje on:

Jest tu prasa skandaliczna, [...] zatruwająca młode umysły półsłówkami przezroczystymi i obrazkami podżegającymi wyobraźnię, której ostrze prawdy i krytyki nie uszkodzi [...] $]^{39}$.

Zapewne w jakiejś mierze opinię o politykierstwie i lewicowości polskich Żydów urabiali znawcy historii Leona Schlessingera, austriackiego kaprala, syna żydowskiego krawca z Wadowic, który - jak czytamy w książce Wiesława Fijałkowskiego Z dziejów Ameryki Środkowej XVI-XIX w.:

uszył sobie mundur oficerski. Gdy aresztowanego odstawiono do macierzystej jednostki, uciekł do Ameryki i znalazł się w Nikaragui. Walker przyznał mu stopień pułkownika i postawił na czele misji dyplomatycznej, gdyż Schlessinger oprócz niemieckiego znał doskonale angielski, hiszpański i francuski $^{40}$.

Ten polski Żyd zyskał sobie przychylność prezydenta Stanów Zjednoczonych, Franklina Pierce’a, co nie podobało się rządom europejskim. Dodajmy: nie podobało się także dziennikarzom amerykańskim, wszak Schlessinger górował nad nimi inteligencją, odwagą, wyobraźnią polityczną, światopoglądowym liberalizmem.

Przypomnieć tu również wypada o wzroście bezrobocia w Ameryce, wynikającym z ciagłego napływu europejskich emigrantów. Jak stwierdził historyk Sławomir Sierecki:

W roku 1877 wybuchło [w Stanach Zjednoczonych] szereg wielkich strajków, które z charakteru walki ekonomicznej przerosły w masową akcję polityczna, a wreszcie w powstanie zbrojne. W tym czasie bezrobocie w USA wzrosło do kilku milionów ludzi, głównie w wielkich ośrodkach miejskich.

W lipcu i sierpniu $1877 \mathrm{r}$. w wielu miastach wprowadzono stan wyjątkowy ${ }^{41}$.

Odpowiedzialnością za trudną sytuację ekonomiczną społeczeństwo obarczało m.in. emigrantów żydowskich. Zjawisko znane nam pod nazwa „szukanie kozła ofiarnego" okazało się wręcz epidemiczne.

Szczęśliwym połączeniem publicystyki i artyzmu jest cykl reportaży Wiśniowskiego Obrazki życia amerykańskiego, w których pisze on o polskich Żydach osiadłych w Chicago i Filadelfii, o codziennych sprawach prostych ludzi. W miastach tych - podkreśla - „potomkowie Abrahama” żyją w bliskim kontakcie z Polakami. Zatrudnieni w tych samych zakładach przemysłowych, wspierają się w pokonywaniu trudności życia. Po pracy bywają razem w teatrze, zwłaszcza gdy na scenie występują polscy aktorzy i można usłyszeć „szmer rodzinny”. Czytamy w reportażu:

S. Wiśn iow s ki, Prasa w Ameryce. „Bluszcz” 1881, nr 10, s. 80.

W. Fij ałk ow s ki, Z dziejów Ameryki Środkowej XVI-XIX w. Warszawa 1988, s. 140.

S. Si e re cki, Prawda i legenda o Dzikim Zachodzie. Wyd. 2. Warszawa 1966, s. 179. Zob. też

M. P a r a fi n o w i c z, Stany Zjednoczone wobec imigrantów. „Przegląd Humanistyczny” 1989, nr 4,

s. 188. 
Zacny rabin filadelfijski odwiedził pierwsze przedstawienie. Mówiono mi, że salę napełnili poczciwi Żydzi, a twarze ich wyrażały rzewność niewymowną, pomimo parodii na scenie! ${ }^{42}$

W reportażu „filadelfijskim” Wiśniowski pisze o trzech Żydach - braciach Remakach z Poznania. Przyjechali oni do Ameryki w wieku niemowlęcym. Choć nie znają języka polskiego, wiedza, gdzie przyszli na świat, gdzie był ich dom rodzinny. W Ameryce zdobyli zawód adwokacki. Reprezentują różne partie, mają odmienne poglądy polityczne. Chca być prawdziwymi obywatelami nowej ojczyzny, móc oddziaływać na politykę krajowa, dlatego sa gotowi do zawierania kompromisów $\mathrm{z}$ innymi lokalnymi grupami. Zdaniem Benedicta Andersona, autora artykułu Kocham ojczyznę, bo daleka, „uczestnictwo w lokalnej polityce jest sposobem wyjścia z zamkniętych wspólnot” ${ }^{43}$. Wiśniowski $z$ wyczuwalną satysfakcją odnotowywał, iż Polacy i polscy Żydzi są zatrudniani w amerykańskich instytucjach państwowych, na kierowniczych stanowiskach. Sam był przez jedna kadencję posłem stanu Minnesota i współpracował z Izraelitami w dziedzinie kultury. Starał się, by zakupione przez Żydów obrazy wielkich polskich malarzy mogły być wystawiane w Stanach Zjednoczonych, aby inteligencja polska o korzeniach semickich integrowała się $\mathrm{z}$ amerykańską, aby dostała się do elit.

Wiśniowski - o czym już wspominano - kilkakrotnie gościł na Kubie. Spotykał tam osiedleńców różnych nacji europejskich, emigrantów z Azji (głównie Chińczyków) oraz z Afryki. W tej palecie wielonarodowej spora grupę stanowili polscy Żydzi, którzy reagowali $z$ radością na obecność reportera-współrodaka. Chętnie opowiadali mu o kraju osiedlenia, o swych potrzebach i oczekiwaniach. Na Kubie - podobnie jak w Stanach Zjednoczonych - prowadzili uliczny handel. Byli operatywni, pogodni, ale też - zdaniem Wiśniowskiego - zbyt łatwowierni. Rozkładając swój towar na wąskich i ruchliwych ulicach Hawany, narażali się na kradzieże ${ }^{44}$. Na szczęście rodowici Kubańczycy nie krzywdzili Hebrajczyków.

W centrum uwagi globtrotera znaleźli się liczni żydowscy kolporterzy:

Najwięcej kolporterów trudni się sprzedażą losów loteryjnych, na które nigdy nie braknie kupców. [...] Los kosztuje czterdzieści dolarów, ale dzieli się na cząstki, aby najuboższy mógł próbować szczęścia. Każdy też gra. [...]

Hawana żyje głównie dla zabawy ${ }^{45}$.

Stwierdzenie: „Hawana żyje głównie dla zabawy” jest zwykłą egzageracją, nie obejmuje bowiem kubańskich niewolników i zapracowanych polskich Żydów. Wyznawców Abrahama drażni wszechwładza hiszpańskich kolonizatorów, zwłaszcza ich agresja wymierzona w czarnoskórych tubylców ${ }^{46}$. Liczni urzędnicy kolonialni,

W iśn i o w s ki, Obrazki z życia amerykańskiego, s. 345.

B. Ander s on, Kocham ojczyznę, bo daleka. Przeł., oprac. K. Koń czal. „Gazeta Wyborcza” 2009, nr z 8-9 VIII, s. 22.

Zob. S. Wi śn i o w s ki, Królowa Antylów. „Gazeta Lwowska” 1879, nr 164, s. 2.

S. W is n i o w s ki, Ze wspomnień o Hawanie. W: W kraju Czarnych Stóp oraz inne nowele, obrazki i szkice podróżnicze. Przedm., oprac. J. Tu w i m, B. Ol s z e w i c z. Warszawa 1954, s. 382. Pisma wybrane. T. 2. (Pierwodruk: „Bluszcz” 1879, nry 28-30).

Zob. ibidem, s. 375-377. Zob. też M. B ar n et, Biografia niewolnika. Przeł. H. C zaj ka. Warszawa 1972. - A. D o mini k, Kuba-perta Antyli. Wyd. 2, uzup. Katowice 1993. 
choć pozują na cywilizatorów, w rzeczywistości są skorumpowanymi zdziercami, stanowią - jak pisze reporter - „przedmiot grozy publicznej” 47 . Wiśniowski uzasadnia negatywne opinie o Hiszpanach słowami:

Nie ma [...] kupca w Hawanie ani plantatora, który by nie musiał znosić obelg osobistych ze strony opieszałych, grubiańskich i ciemięgowatych urzędników hiszpańskich na komorze celnej; każdy turysta i komiwojażer zagraniczny musi poznać arogancję tych panów, wykorzystujących z niesłychaną formalistyczną precyzją zawiłe ustawy paszportowe rządu hiszpańskiego. Dodajmy, iż uczciwi kupcy rujnują się wobec konkurencji z niegodziwymi [... $]^{48}$.

Społeczeństwo Kuby - udobitnijmy ten fakt - przypomina Wiśniowskiemu „pobielane grobowce Pisma Świętego, białe na zewnątrz, wewnątrz pełne zgnilizny"49. Galicyjski globtroter potępiał obojętność znacznej części Europejczyków wobec deptania przez kolonizatorów podstawowych wartości ludzkich. Czy postrzegli i docenili to jego warszawscy krytycy?

Kubańskie reportaże Wiśniowskiego mają dwie podstawowe zalety. Stanowia owoc pionierskiego poznania dalekiej przestrzeni, w którą wtopili się polscy Żydzi. Uwydatniają również wartość funkcjonowania w Ameryce Środkowej elementu „polskości” dzięki żydowskim emigrantom z Przywiślańskiego Kraju.

Uwzględniając kwestię żydowską w swoich reportażach, Wiśniowski skupia się na prezentacji „świata męskiego”. Kobiety żydowskie nie istnieją w zewnętrznej rzeczywistości obczyzn, egzystują w „domach” - miejscach zamieszkania. Zapewne wolniej niż ich ojcowie, bracia i mężowie przystosowują się do nowych warunków, pokonują lęk społeczny ${ }^{50}$. Słusznie zauważyła Hana Wirth-Nesher, autorka studium poświęconego emigrantom: „W wymiarze jednostkowym każde wykorzenienie jest bolesne" ${ }^{51}$. Asymilacja - podkreślmy ten fakt - ,jest procesem ogromnie skomplikowanym, a raczej zespołem procesów społecznych, psychologicznych, a także przemian instytucjonalnych, w których wyniku jednostki i grupy pochodzące $z$ innych społeczeństw i kręgów kulturowych zostają w kraju osiedlenia powoli przetworzone w sferze zachowań i przynależności strukturalnej” 52 . Zasób wiedzy galicyjskiego podróżnika o problemach emigrantów żydowskich, o naturze procesu asymilacyjnego był imponujący, co mogło bulwersować czy nawet drażnić krajowych dziennikarzy. Albo tylko nudzić.

Reportaże Sygurda Wiśniowskiego przybliżały czytelnikom sytuację polskich Żydów, którzy na odległych kontynentach szukali stabilizacji życiowej. Wedle spostrzeżeń globtrotera osoby starsze cechowała „polska tęsknota”, natomiast młodzi

J. Zu br zy c ki, O asymilacji i wielokulturowości. W: Społeczeństwo i socjologia. Księga poświęcona Profesorowi Janowi Szczepańskiemu. Wrocław 1985, s. 321. Zob. też H. Mark i e wi i z, Asy-

milacja Żydów jako temat literatury polskiej. W: Literatura i historia. Kraków 1994, s. 15.

W iśn i o w s ki, Królowa Antylów, s. 1.

W iśn niow s ki, Ze wspomnień o Hawanie, s. 377-378.

Ibidem, s. 393.

Zob. K. Oatley, J. M. Jenkins, Zrozumieć emocje. Przeł. J. Radzicki, J. Suchecki. Warszawa 2003, s. 90, 128, 168.

H. Wirth-Nesher, City Codes. Reading the Modern Urban Novel. Cambridge 1996, s. 29-30. Podaję za: M. Ad a m c zy k - Ga r b ow s ka, Odcienie tożsamości. Literatura żydowska jako zjawisko wielojęzyczne. Lublin 2004, s. 118. 
Semici, aczkolwiek nie odcinali się od kraju przodków, stosunkowo szybko wchodzili w strukturę społeczeństwa przyjmującego.

W Stanach Zjednoczonych zaobserwował Wiśniowski różne przejawy antysemityzmu, m.in. poniżanie Żydów, wyrzucanie ich poza nawias lokalnej wspólnoty, uważanie Semitów za wcielenie zła. Mając szczególną zdolność wyczuwania bezpodstawnych animozji, przewidywał, iż w przyszłości może nastąić eksplozja szaleństwa, które uderzy w Izraelitów tylko dlatego, że są „inni”. Udobitniał niebezpieczeństwo negatywnych stereotypów. W roku 1879 spod jego pióra wyszły bardzo ważne słowa:

Niełatwo wyleczyć się z fałszów, którymi umysł poił się w młodości. Większość ludzi w średnim wieku pełną jest przesądów i utartych komunałów, które wypaczają sąd i zmysły nawet. Trudno im zrozumieć rzeczywistość, znaleźć w nowości dobrą stronę, nagiąć się do zmian epoki, do objawów ducha czasu, do wymagań obcego otoczenia. $Z$ tym popędem konserwatywnym muszę się łamać w każdej nowej podróży, aby nie krzywdzić w opinii publicznej społeczeństwa, jakie poznaję ${ }^{53}$.

Wiśniowski rozumiał pokrzywdzonych, ale rozumiał też mechanizm krzywdy. To już niezwykła sztuka.

Abstract

KAZIMIERA ZDZISŁAWA SZYMAŃSKA Jan Długosz University, Częstochowa

\section{POLISH JEWS ON THE JOURNEY TRACK OF A GALICIAN GLOBETROTTER SYGURD WIŚNIOWSKI}

Sygurd Wiśniowski (1841-1892), Galician globetrotter, writer and literary reporter, piercingly fathomed the world mysteries of the second half of the $19^{\text {th }}$ century. His interests included the reasons and effects of the growing emigration tendencies from Europe to Australia, the USA and Cuba, emigrant assimilation, and their competition on the labour markets. In his literary reports published in Lviv and Warsaw press Wiśniowski often wrote about the waves of emigrants from Poland, and was especially absorbed by Hebrew emigrants. Among the Polish Jews he kept contact with were wealthy merchants, street vendours, but also beggars; people of different age. Wiśniowski took note of their Polish sensitivity, melancholy, yearning for the country on the Vistula, fear of loss of identity. His accounts break with the stereotype of a Jew - a cunning fox, a heartless rich man, a Christian foe, and also emphasise the intensified anti-Semitism in the USA. In his assessment, the Germans demonstrated special bellicosity towards the Polish Jews. Wiśniowski's political, anthropological, and sociological competencies hold respect of the reports' readers. Kraków 1995. 